\title{
MÁRIO DE ANDRADE E O PRIMEIRO DE MAIO DE 35
}

Iná Camargo COSTA ${ }^{1}$

- RESUMO: Entre os anos de 1934 e 1942, Mário de Andrade escreveu o conto "Primeiro de Maio", publicado no livro póstumo Contos Novos. A leitura aqui apresentada, ao mesmo tempo em que propõe uma data para a ação, procura rememorar alguns aspectos da história das lutas da classe trabalhadora, vinculados a esse dia e suscitados pelos achados literários do conto.

- PALAVRAS-CHAVE: Primeiro de Maio; celebração; comemoração; ficção; história; luta de classes.

“Vem ó maio, saúdam-te os povos!

Nós queremos remir este mundo Dos senhores da terra e das vidas."

(P. Gori, Hino do Primeiro de Maio)

1 Quem viu São Bernardo do Campo militarmente ocupada naquele gélido e cinzento Primeiro de Maio de 1980 empaca logo no primeiro parágrafo do conto de Mário de Andrade: "No grande dia Primeiro de Maio, não eram bem seis horas e já o 35 pulara da cama, afobado. Estava bem disposto, até alegre, ele bem afirmara aos companheiros da Estação da Luz que queria celebrar e havia de celebrar" (Andrade, 1983, p.39).

Deixemos de lado, por enquanto, o índice "35" do personagem. O estranhamento provém antes da sua intenção: celebrar o Primeiro de Maio. Como assim? O Primeiro de Maio não é o dia mundial de luta dos trabalhadores? Não é dia de homenagear aqueles companheiros barbaramente assassinados em Chicago através de atos públicos (ocupação das ruas), que aqui no Brasil chegam a ser reprimidos até pelo exército? Ou não existe diferença entre celebrar (festivamente) e comemorar (luto, protesto e luta) uma data? Este primeiro problema vai determinar o resto da leitura do conto,

1 Professora do Departamento de Teoria Literária e Literatura Comparada - FFLCH - USP - São Paulo - SP - Brasil. 
pois estão em jogo duas diferentes concepções de Primeiro de Maio: a celebrativa do 35 e a do leitor que o entende como um dia de luta.

Resumindo muito esquematicamente os dados históricos disponíveis, comecemos respondendo a uma pergunta prévia: Por que primeiro de maio? Sem levar em conta as explicações que remetem à esfera mitológica e também podem ter o seu interesse, na medida em que os social-democratas europeus a certa altura (já veremos quando) recorreram a elas, a razão histórica é mais ou menos esta: nos Estados Unidos do século passado, a data-base (como se diz hoje) de inúmeras categorias de trabalhadores era o dia primeiro de maio, chamado moving day, dia de celebração de contratos de trabalho (cf. Del Roio, 1986, p.57-64). Por isso a AFL (Federação Americana do Trabalho), na luta pela redução da jornada a oito horas, convocou para o Primeiro de Maio de 1886 uma paralisação e um ato público. O resto dessa história é conhecido: passeata e ato público no dia primeiro, assassinato de seis grevistas no dia três, outra manifestação de protesto no dia quatro, estado de sítio, prisão, julgamento e execução - a 11 de novembro daquele ano - dos líderes anarquistas, os mártires de Chicago. Desde então, pelo menos para os anarquistas, o Primeiro de Maio passou a ser um dia de luto e luta pelas oito horas, sempre comemorado com greves, atos públicos, comícios e passeatas. Os socialistas da Segunda Internacional inicialmente adotaram a bandeira de luta, convocando greves e atos públicos, mas já no ano de 1890 começaram a mudar de tom. Conquistada a legalidade e a representação no parlamento germânico, para evitar confrontos de classe "desnecessários no momento", o SPD (Partido Social Democrata Alemão) retirou da pauta a proposta de greve e introduziu a novidade festiva: celebrar as suas (reais) vitórias. E no ano de 1891 a Segunda Internacional aprovou a proposta de transformar em feriado o dia Primeiro de Maio e tornar permanente a celebração dessa festa. A mitologia começa no momento seguinte.

Aqui no Brasil, as coisas sempre aparecem entortadas pela colher da classe dominante. E como ela sempre exerceu o seu domínio com a mais cordial das ferocidades, não são de estranhar os termos de um certo Dr. Porfírio de Aguiar relatando uma das mais antigas comemorações do Primeiro de Maio em São Paulo:

Ainda não há 60 dias que em São Paulo nós também vimos as festas do trabalho, a primeiro de maio celebradas, mais ou menos ao modo de lá [a Europa], com o mais solene e ruidoso atrevimento; vimos aquelas massas desenvoltas e de revoltante aspecto; aquele préstito insolente de alguns mil homens; aquele absurdo vivo a percorrer as ruas em destemperada passeata entre brados e ameaças; vimos aqueles estandartes e bandeiras ufanas e desfraldadas; aquelas divisas néscias e paradoxais, aquelas inscrições brutais, criminosos pregoeiros da guerra social; símbolos sem dúvida de uma selvageria que, entre nós, nada justifica, nada atenua. (Carone, 1984, p.232-3, grifos nossos)

Recorrendo desde já (será casual?) às idéias de festa e celebração, o Dr. Porfírio se refere com visível horror ao Primeiro de Maio de 1889. É compreensível sua 
dificuldade para admitir o cabimento do protesto. Naquele ano, como se sabe (segundo a classe dominante), na ordem do dia estava a questão republicana e não as trabalhistas. Além disso, também segundo a visão dominante, nem sequer havia capitalismo no Brasil, não podendo portanto haver classe operária e muito menos luta de classes...

Na primeira década deste século, a classe operária em São Paulo chegou a figurar na vanguarda da luta pela jornada de oito horas. Para dar um exemplo, o Primeiro de Maio de 1907, convocado pelos anarquistas - que desde o ano anterior já se manifestavam contra as propostas de festa e celebração (identificadas como tática dos católicos e social-democratas) -, transformou a Praça da Sé em praça de guerra, pois a concentração foi proibida e tropas armadas ocuparam as ruas do centro para impedi-la. Prisões, espancamentos, expulsão de estrangeiros (anarquistas, evidentemente) não impediram a continuidade desta luta, enquanto socialistas à brasileira desde 1895 já vinham reivindicando a transformação do dia primeiro de maio em feriado - Festa do Trabalho!

Por certo não se pode computar entre os feitos deste tipo de socialistas a criação do feriado, mas não há por que duvidar de que o decreto de Arthur Bernardes (de 1924, passando a vigorar em 1925) em alguma medida se aproveitou dessa inspirada sugestão. O historiador que estamos acompanhando assim comenta mais esta singular ocorrência: "Entre nós, o feriado nacional de $1^{\circ}$ de maio foi decretado antes que existisse lei federal de limitação da jornada de trabalho a oito horas, ou seja, a classe dominante fez o impossível, transformou em festa nacional a comemoração de um objetivo que não se atingiu. Extraordinário!" (Del Roio, 1986, p.141-2)

Aliás, Arthur Bernardes, um inimigo do gênero humano, do ponto de vista do movimento operário, realizou outros feitos "trabalhistas" igualmente extraordinários em seu movimentadíssimo mandato presidencial (1922-1926). Mas costuma ser lembrado pelos dois " 5 de julho" tenentistas (1922 e 1924), que tiveram seu mandato como alvo principal e lhe deram o pretexto necessário para governar em permanente estado de sítio, travando uma feroz guerra contra as organizações e lideranças da classe operária, numa espécie de prévia do que aconteceria com Getúlio em 1936, depois das quarteladas de novembro de 1935.

Cabe ainda lembrar que a história mundial do Primeiro de Maio, a partir dos anos 20, incorporou um novo personagem: a Revolução de 1917, pois, com toda a razão, na União Soviética o dia se transformou numa das festas máximas. Entretanto, a partir da vitória do exército vermelho na guerra civil, o ponto culminante da celebração passou a ser um desfile militar, para horror de anarquistas, social-democratas e outros militantes menos votados, inclusive brasileiros, que tiveram oportunidade de presenciar tal demonstração pública de que alguma coisa não dera certo naquela original experiência política, dita comunista.

Diante de tais informações, a disposição de 35 para celebrar o Primeiro de Maio tem uma função literária muito mais importante do que apenas despertar a estranheza de leitores um pouco mais aguerridos. 
2 O primeiro parágrafo do conto ainda pressupõe outras informações histónicas que é preciso recuperar: o feriado, o número 35 e a inserção do personagem na força de trabalho.

Embora já saibamos que o feriado é de 1924, consta que foi decretado em 1938 por Getúlio Vargas nos preparativos do seu marketing proletário. Se é verdade que a Revolução de 1930 revogou toda a legislação anterior, também o é o fato de que Getúlio não usurpou apenas o poder, mas ainda os "feitos trabalhistas" de seus antecessores. Por isso, não admira a nossa maior facilidade para encontrar referências ao decreto de 1938 do que ao de 1924. Mas, como o conto de Mário de Andrade foi escrito entre 1934 e 1942, a referência ao feriado com claras indicações de que a ação não se passou em 1939, ou depois, pode ter tido a modesta função de indicar que as "festas do trabalho" da era getulista no estádio do Vasco da Gama, inauguradas no $1^{2}$ de maio de 1939, tinham também uma pré-história. O conhecido ceticismo de Mário estaria funcionando aqui ao menos para questionar a originalidade da iniciativa do ditador. Por isso, um dos momentos mais terríveis do conto - a "celebração oficial" no Palácio das Indústrias - precisa ser visto em sua possibilidade de mostrar que se o pequeno grande "pai dos trabalhadores" (e mãe dos patrões) tinha algum mérito, este era o de saber se apropriar da experiência acumulada da classe dominante e, se possível, como neste caso, aperfeiçoá-la.

O 35, que funciona como "identidade" do personagem, não tem nada de cabalístico, tratando-se de um recurso rigorosamente anti-realista (não é assim que trabalhadores, mesmo se sabendo seriados, se tratam entre si). Se Mário optasse por qualquer nome comum ou apelido, deixaria passar a oportunidade de referir sinteticamente a data em que este primeiro de maio transcorreu e evidenciar o caráter de elaboração artística de seu conto (e não de reportagem, por exemplo). A exposição enfática das marcas da elaboração literária faz parte do repertório antiilusionista da literatura moderna, que nem por isso é menos realista, por mais paradoxal que isso possa parecer a leitores apressados.

Que informações o Autor quis passar nomeando seu personagem como número 35? Alguns leitores apontaram tão bem o fenômeno da despersonalização configurado neste gesto artístico que não precisamos voltar ao assunto. Mas embora se refiram aos gravíssimos acontecimentos políticos daquele malfadado ano de 1935 (sobretudo o breve movimento da Aliança Nacional Libertadora (ANL) e as malogradas tentativas de golpe militar de novembro), não se estabelece relação com o dia de luta dos trabalhadores. Para afirmar que este é o Primeiro de Maio de 1935, além de estabelecer que o feriado já existia desde 1924, é preciso trazer à memória (significado literal de comemorar, como se sabe) mais alguns detalhes sobre os fatos históricos daquele ano.

Comecemos pela ANL. Trata-se da versão brasileira da política de Frente Popular dos stalinistas (Terceira Internacional), criada em 1934, assim como na França e na Espanha, e aqui oficialmente lançada em 1935, pegando como fogo em palha seca, por assim dizer. Não se sabe se porque o incêndio ameaçou mesmo sair do controle 
ou porque a nossa classe dominante nunca brincou em serviço quando se trata do controle político, antes mesmo de a ANL sair da clandestinidade, Getúlio encaminhou ao congresso, "democraticamente" eleito no ano anterior, a Lei de Segurança Nacional. Chamada de Lei Monstro por unanimidade entre os militantes do movimento sindical em pleno processo de atrelamento ao Ministério do Trabalho, essa lei foi aprovada a 30 de março de 1935. Seu alvo não foi apenas a nascente ANL, como demonstra a proibição sumária das organizações independentes dos trabalhadores que nela figura.

O quadro pressuposto neste conto contém, pois, pelo menos, os seguintes fatos históricos: uma Lei Monstro em vigor, um movimento de Frente Popular em andamento, uma constituição "democrática" recém-votada pelo Congresso (a de 1934) e a proibição (explicitamente referida) das comemorações independentes do Primeiro de Maio, devidamente enquadradas no conceito de atentado à segurança nacional. Contam ainda alguns historiadores que nesse dia um comício antifascista no Rio de Janeiro foi dissolvido a poder de polícia e cavalaria.

Resta ainda examinar a qualificação de 35 como trabalhador. Que ele não é operário fica claro logo no primeiro parágrafo; trata-se de um carregador de malas que trabalha na Estação da Luz (da Ferrovia Paulista, assim como a Estação do Norte era da Central do Brasil). Esta determinação do personagem faz parte do processo fundamental da exposição da narrativa neste conto, tendo razões de ordem histórica e resultando numa questão de técnica literária - o discurso indireto livre.

O interesse de Mário de Andrade por questões relativas à luta de classes data do final dos anos 20 e sua evolução pode ser acompanhada sobretudo através de algumas cartas. Em 1932, por exemplo, passada a ressaca da "revolução constitucionalista", ele escreve as seguintes linhas a Carlos Drummond de Andrade:

Dos quase 200 mil operánios de fábricas paulistas, muitos trabalhados pelo comunismo, a contribuição de voluntários para guerrear não foi mínima, foi nula. ... E de certas modalidades do proletaniado a contribuição foi formidável. Sitiantes, chauffeurs, criados, empregados, todos amaram sublimemente, não a Constituição, mas a guerra de São Paulo. (Andrade, 1988, p.167, grifos nossos)

Note-se que, mesmo numa carta em que o rigor conceitual não é propriamente exigido, Mário mostra entender operário como uma modalidade do proletariado, como os clássicos do marxismo. Se numa carta, escrita ao sabor da inspiração, nosso Autor tem o cuidado de estabelecer a distinção, o que dizer de um conto que levou oito anos para ser considerado pronto? No mínimo, que a classe do 35 é o proletariado, embora - por razão decisiva para a exposição do conto em discurso indireto livre - não seja operário, nem sequer assalariado: 35 é um carregador, cuja féria depende dos passageiros da Estação da Luz. Por isso mesmo está em contacto com uma das categorias mais aguerridas e bem organizadas da época: os ferroviários da Paulista, que realizaram no ano de 1933 uma greve envolvendo a impressionante cifra de 10 
mil trabalhadores (para mencionar só um episódio de suas lutas). Por essa proximidade, alguma coisa da afirmação da classe proletária à qual pertence o 35 sabe. Sem falar que, por haver à época respeitável presença comunista nessa categoria, ele pode estar muito mais próximo da situação de "área de influência" do que parece.

Operando ainda a necessária aproximação entre o feriado e o tipo de trabalho do 35, vamos chegar a outra determinação prevista pelo Autor e já insinuada quando examinamos a intenção de celebrar o Primeiro de Maio. Mas para isso temos de recorrer aos companheiros dele: "Os outros carregadores mais idosos meio que tinham caçoado do bobo, viesse trabalhar que era melhor, trabalho deles não tinha feriado. Mas o 35 retrucava com altivez que não carregava mala de ninguém, havia de celebrar o dia deles" (Andrade, 1983, p.39).

Do ponto de vista daqueles trabalhadores, a atitude do companheiro é boba por significar apenas prejuízo. Objetivamente, o gesto não é político e suas conseqüências são individuais. Mas ele é altivo (opinião do narrador) e está disposto a pagar o preço de sua celebração. Este é o dado novo: a sua disposição (alegre) para o sacrifício voluntário e individual (heróico) e, com ela, uma tênue, mas real, marca da sua criação cristã, que prepara o solo onde a idéia de celebração deita as raízes mais férteis no Brasil.

3 Sua formação religiosa é católica: "chegara até a primeira comunhão em menino" e achava lindo o interior da Igreja de São Bento. Ele foi criado num lar saudável onde aprendeu a honrar pai e mãe. O narrador destaca a reverência à memória do pai (com a navalha herdada) e o respeito cuidadoso com que fica nu só da cintura para cima devido à presença da mãe. Ao lado dessa sólida estrutura familiar (material para interessante análise psicanalítica), atuou a escola transmitindo-lhe importantes valores nacionalistas (agora em processo de capitalização pela ANL): o 35 vestiu-se de bandeira brasileira, gravata verde-e-branco e sapatos amarelos, lembrando-se dos tempos de grupo escolar (" $E$ o 35 comoveu num hausto forte, querendo bem o seu imenso Brasil, imenso colosso gigante" - (Idem, p.40). Fica claro também que sua vida escolar parou por aqui, pois de outra forma não seria um carregador de malas, mas foi suficiente para que ele aprendesse a ler com razoável competência, como veremos no capítulo de seu consumo de informações.

Ainda no quadro de sua formação cristã, na abertura do quarto parágrafo temos que "o 35 apressou a navalha de puro amor. ... Uma piedade, um beijo lhe saía do corpo todo, feito proteção sadia de macho" (Idem, p.39). O complemento deste ímpeto amoroso está no final do episódio "Palácio das Indústrias": "Tinha piedade, tinha amor, tinha fraternidade, e era só. Era uma sarça ardente, mas era sentimento só" (Idem, p.45).

Esses passos, que enquadram de maneira decisiva a disposição para o sacrifício, só podern ser entendidos na órbita do sentimento cristão do amor abstrato, da fraternidade abstrata que, como já nos mostrou exaustivamente a história - e continua mostrando -, devidamente manipulado por bons conhecedores de psicologia barata, 
resulta em feitos heróicos ou fanáticos (dá na mesma) de gente que nada teme, nem a morte. O 35 apresenta o solo muito bem adubado para a germinação das sementes do fanatismo (o integralismo já estava em cena). Felizmente, Mário de Andrade, talvez graças a seu lado socialista, nos poupou dessa provação evitando que ele caísse nas garras do integralismo, mas os dados para uma resolução literária dessa ordem estão presentes e contam entre os materiais que conformam um personagem não linear, em movimento.

O eixo principal da tensão se constrói no contraponto entre sua formação (Deus, Pátria e Família) e sua condição de trabalhador que lê jornais (provavelmente também as publicações clandestinas dos comunistas): "Com seus vinte anos fáceis, o 35 sabia, mais da leitura dos jornais que de experiência, que o proletariado era uma classe oprimida. E os jornais tinham anunciado que se esperavam grandes "motins" do Primeiro de Maio, em Paris, em Cuba, no Chile, em Madri" (Idem, p.39).

Aqui encontramos o motivo para afirmar que sua leitura é razoavelmente competente: ele não sabe inglês e faz "tradução fonética" de palavras dessa língua nos jornais (legais ou clandestinos); leu meeting (ato público, comício) e traduziu "motim". Escrevendo motim entre aspas, o narrador estabelece uma convenção: no seu uso particular do discurso indireto livre, em alguns momentos distancia-se explicitamente do personagem, de modo a não endossar pensamentos e palavras, assim podendo adicionalmente chamar a atenção do leitor. Mas o grande estudioso de Psicologia que era Mário de Andrade queria mais. Esta tradução não está propriamente errada. Freudianamente, Mário a classificaria no número dos atos falhos. Adaptando a expressão corrente, diríamos que o 35 pratica uma espécie de wishful reading e com ela faz uma espécie de justiça poética que pressupõe uma fusão de múltiplos dados: motim na língua que o povo fala (e Mário conhecia como ninguém) é sinônimo de "turumbamba macota" (aqui temos duas "gírias", uma de origem tupi, que também nos deu sururu e surumbamba, todas significando confusão, convulsão, desordem, e outra proveniente do quimbundo, que quer dizer grandioso). Com a expectativa de participar de um fuzuê dessa ordem, de um motim, nada mais natural que "ler" nos jornais a notícia de que em países como França, Espanha, Cuba e Chile - na ordem do dia por razões semelhantes ${ }^{2}$ - esperavam-se motins no Primeiro de

\footnotetext{
2 São razões mais propriamente revolucionárias: a ditadura de Primo Rivera na Espanha caiu em 1930, a de Gerardo Machado em Cuba em 1933 e em 1932 o Chile experimentou uma brevíssima "revolução socialista". Em todos eles, como no Brasil, em 1935 está em pleno andamento a estratégia das Frentes Populares, lançada pela Terceira Internacional no ano anterior. Essa política, na origem de nossa ANL de curta existência, levou Léon Blum ao poder na França em 1936, assim como elegeu o governo espanhol em fevererro desse ano. A experiência mais didática, por assim dizer, foi a da Espanha, que em julho do mesmo ano assistiu à contra-revolução falangista, seguida dos conhecidos horrores da Guerra Civil. Apenas cinco dias após o início do levante fascista, Trotski avalia o papel da Frente Popular na Espanha e escreve o seguinte prognóstico, tão sombrio quanto correto: "A Frente Popular criou as condições favoráveis para a vitória do fascismo ao adormecer operários e camponeses com ilusões parlamentaristas, paralisando sua vontade politica. A politica de alianças com a burguesia vai custar caro à classe operária, anos de sofrimentos, de sacrifícios, se não décadas de terror fascista" (Trotski, p.46, grifos nossos).
} 
Maio. Mas a justiça da tradução vai ainda mais longe: ela é o verdadeiro conteúdo político de notícias sobre o primeiro de maio veiculadas no discurso e na imprensa da classe dominante. Para esta, sobretudo na sua versão local, meetings de trabalhadores são motins mesmo, coisa de baderneiros, amotinados, inimigos da ordem e da "paz" social, do interesse de "todos"... menos do 35, que está mesmo a fim de turumbamba e dos macotas.

O acesso do personagem à imprensa clandestina se encontra na afirmação de que ele sabia da leitura dos jornais ser o proletariado uma classe oprimida. E como as referências à Rússia a tornam "só horrenda ou só sublime", já se vê que o personagem só conhece jornais conservadores ou stalinistas. ${ }^{3}$

Esta esperança de participar de um turumbamba ("para dar uns socos formidáveis nas fuças dos polícias") talvez não deva ser explicada só pela "tradução" dos meetings dos jornais. Uma relação deste tipo não se estabelece só através de leituras (de intertexto). De algum motim o 35 há de ter participado, e motim antifascista foi 0 que não faltou no ano de 1934. O mais próximo deste Primeiro de Maio ocorreu a 7 de outubro de 1934. Segundo o relato de Fulvio Abramo, um saudoso veterano dessa batalha, naquele domingo haveria um comício integralista na Praça da Sé, chegando a reunir cerca de seis mil pessoas armadas. A recém-formada Frente Única Antifascista (FUA) convocou os adversários do integralismo para dissolvê-lo. Mais de 20 mil pessoas compareceram ao contracomício e realmente houve um turumbamba macota, com diversas mortes dos dois lados (cf. Abramo, p.38). Para enquadrar ainda mais a ação

3 Mais de uma vez nosso Autor formulou sua opinião sobre os comunistas (stalinistas) brasileiros. Na carta a Drummond, já citada, assim avaliou a atuação deles na chamada Revolução de 32: "Os comunistas partidários que querem fazer da guerra paulista um movimento exclusivamente burguês mentem por pragmatismo, no seu já famoso pragmatismo que no Brasil se transformou notoriamente em licença pra todas as safadezas." Ele não se alinhava, porém, nas fileiras do confusionismo e acompanhava com bastante inquietação o maniqueísmo combinado com fanatismo anticomunista da classe dominante, que cuidadosamente cultivava (só no passado?) a ignorância generalizada sobre os fatos. É de impressionante atualidade a seguinte observação de Mário a esse respeito, numa crônica de 1930: "O que nos leva ao pavor que temos pelo comunismo é a identificação deste com a Rússia, por ser esta a primeira e única nação que o aplicou verbalmente até agora. Antes de mais nada, a verdade verdadeira é que ninguém não sabe direito o que é a Rússia contemporânea nem o que está sucedendo por lá. Uma circunstância fatal do regime político internacional em que estamos vivendo. Os paises capitalistas têm feito tudo não só para ocultar da humanidade a Rússia verdadeira, como ainda têm feito tudo para prejudicá-la até internamente. Por seu lado a Rússia havia de reagir, está claro. Se defende. Os outros lhe exageram as mazelas. Ela sequestra as mazelas que tem. E essas manipulações da verdade provêm duma confusão pueril dos conceitos de governo e de felicidade. ... Ora se a Rússia geme de muitos malestares (e isso depende em parte enorme da situação internacional em que a colocaram os outros países) também é incontestável que esses malestares não são piores que os da Alemanha, que os da Índia, que os do Brasil uochintoniano. E goza de muitos bem-estares também." (Andrade, 1976b, p.282, destaques nossos). A mesma clareza aparece em carta de 1936 a Murilo Miranda, a propósito da não-adesão a uma homenagem a Romain Rolland: "eu esclareci pra você a minha situação em face dos problemas sociais da época ... eu creio que estava suficientemente definido que, apesar das francas simpatias, eu guardava comigo certas conviç̧ões que tornavam absolutamente impossível uma adesão sem reservas à ideologia marxista e consequente mergulho no Comunismo. Jamais não tomei compromisso algum, e nem principalmente prometi uma futura adesão. E isto é tanto mais leal, que sei que o comunismo há de vir." (Andrade, 1981, p.39). 
do conto, a sua expectativa de rapaz forte ecoa um outro acontecimento bastante datado, de caráter esportivo: refere-se, em sua vontade de dar socos, a Primo Carnera, o campeão mundial dos pesos-pesados nos anos de 1933 e 1934.

Com essas expectativas, e achando-se lindo na roupa preta de luxo, o 35 vai orgulhosamente para o sacrifício.

4 Não sendo o caso de reconstituir a sua "via crucis"; as quase 12 horas da "ação" deste conto expõem o processo de destruição do orgulho do trabalhador. A causa, espantosa, vai enunciada no segundo parágrafo da "saída" deste anti-herói: "ele estava celebrando e não tinha o que fazer". Mário de Andrade está dizendo que 35 é desorganizado no sentido político. Mesmo sendo área de influência do Partido Comunista (ou por isso mesmo), não recebeu nenhuma direção sobre o que fazer nesse Primeiro de Maio. O narrador trabalha a idéia da desorganização política de seu personagem através de uma analogia bastante pesada com a idéia de disponibilidade, ligada à de prostituição, contra a qual os dois lutam: "[o 35 está no Jardim da Luz e] já passavam negras disponíveis por ali. E o 35 teve uma idéia não muito pensada, recusada, de que ele também estava uma espécie de negra disponível, assim. Mas não estava não, estava celebrando, não podia acreditar que estivesse disponível e não acreditou" (Idem, p.41).

O 35 não acreditou, o narrador não gosta muito da idéia, mas foi essa a palavra que ambos encontraram para esse lamentável estado de desorganização do rapaz, só nomeado pelo narrador mais adiante: "Estava tão opresso, se desfibrara tão rebaixado naquela mascarada de socialismo, naquela desorganização trágica, o 35 ficou desolado duma vez" (Idem, p.45).

A trajetória deste avulso imbuído das melhores intenções celebrativas se dá em três níveis: o das percepções, o da memória e o da informação jornalística. Ele percebe que a cidade está ocupada pela polícia e esvaziada de população (por causa do feriado), mas não relaciona a soldadesca à repressão política e sim a seu papel de proteção à propriedade. E, muito esperto, refere-se a esse lado ostensivo daquele despropósito policialesco: “Tinha mas era muito polícia, polícia em qualquer esquina, em qualquer porta cerrada de bar e café, nas joalherias, quem pensava em roubar! nos bancos, nas casas de loteria. O 35 teve raiva dos polícias outra vez" (Idem, p.40).

Dentre as lembranças, pelo menos duas são relevantes: o jogo de futebol à tarde e o piquenique "a doze paus o convite" em Santos. Ele entende estas informações quando as aproxima: "então conseguiu imaginar que esse piquenique monstro, aquele jogo de futebol que apaixonava eles todos, assim não ficava ninguém para celebrar 0 Primeiro de Maio, sentiu-se muito triste, desamparado" (Idem, p.43).

Mas está claro que ele entende apenas o objetivo de esvaziar a cidade (ou pelo menos o centro); não tem meios de se dar conta do que está por trás desse objetivo. Quanto às informações trazidas pelo jornal, temos a proibição policial de comícios e passeatas, uma vaga referência a motim na Praça da Sé à tarde, devidamente 
aguardado por policiais em metralhadoras, a visita dos deputados trabalhistas e a celebração (com a presença do Secretário do Trabalho) no Palácio das Indústrias, ${ }^{4}$ mas no pátio interno, o que despertou a imaginação preventiva do trabalhador: "Não era medo, mas por que que a gente havia de ficar encurralado assim! É! é pra eles depois poderem cair em cima da gente, (palavrão)!" (Idem, p.41).

O 35 programa o seu dia depois da leitura do jornal: reiterando e dando conseqüência à desorganização já estabelecida, o narrador deixa que este destino se decida segundo as cartas oferecidas pela imprensa da classe dominante. Suas ações subseqüentes são o resultado desta equação política: vai recepcionar alguns deputa$\operatorname{dos}^{5}$ na Estação do Norte mas chega atrasado; vai para casa e mal consegue almoçar; dirige-se ao Palácio das Indústrias mas acaba não entrando, como dezenas de operários também endomingados; passa pela Praça da Sé e não vê o motim vagamente anunciado - vê apenas uma multidão (durante cerca de três horas!). Enfim, para o 35 não houve Primeiro de Maio.

Leitores atentos já examinaram o aspecto humano deste conto: o personagem passa o dia todo sozinho e mal consegue se relacionar com apenas duas figuras, 0 486 e o 22, como ele, apenas índices. Mas essa trajetória solitária de um trabalhador justo no Primeiro de Maio tem um significado político e literário que precisa ser explicitado.

O tema indivíduo x multidão já foi tratado outras vezes por Mário de Andrade: por ocasião dos comícios de 1932, no Diário Nacional, e quando fez seu balanço do movimento moderno, apresentando um mea culpa por se considerar um indivíduo que permaneceu à margem. É quando aconselha: "não fiquem apenas nisto, espiões da vida, camuflados em técnicos da vida, espiando a multidão passar. Marchem com as multidões" (Andrade, 1976a, p.225).

No caso da crônica, Mário apresenta-se como o indivíduo que se integra completamente ao ritmo da multidão reivindicando os direitos da cidadania (cf. Andrade, 1976b, p.505-6), em flagrante contraste com o protagonista do conto que saiu de casa exatamente à procura desse tipo de experiência. Este não a encontrou, nem poderia, naquilo que junto com o narrador chamou de mascarada de socialismo, e depois não a pôde encontrar na Praça da Sé porque, independentemente do que lá pudesse ter acontecido naquelas inquietantes três horas (um comício do PCB/ANL?), ele já estava derrotado, suas energias esgotadas.

Não teria interesse o contraste se não levássemos em conta a diferença essencial entre os dois meetings. Para o de 1932, o povo paulista foi amplamente convocado, enquanto o 35 foi a um "motim" vagamente mencionado e para uma "celebração" usurpadora do Primeiro de Maio, tudo filtrado pela imprensa da classe dominante.

\footnotetext{
4 A primeiro de maio de 1934 houve nesse local uma manifestação proletária, convocada entre outros pelo Sindicato dos Bancários e contando com a adesão da FUA (cf. Karepovs, 1994, p.40).

5 Trata-se de deputados ditos classistas, eleitos com "programas progressistas" para a Constituinte de 1934.
} 
Acontece que justamente essa diferença é reivindicada pelo conto. Recapitulando: depois de mostrar o nebuloso conhecimento do 35 sobre a União Soviética, previamente mencionando a provável simpatia pelo comunismo, o narrador alerta: "e o 35 infantil estava por demais machucado pela experiência para não desconfiar, o 35 desconfiava" (Andrade, 1983, p.39-40). Se esta desconfiança incide sobre o noticiário que dependia das idéias políticas dos repórteres, ela incide também sobre a experiência que o machucou em criança. Ele teria 17 anos quando aconteceu o comício da crônica, estopim de um processo político mistificador e manipulado que chegou a envolver até mesmo um cético do quilate de Mário de Andrade. E aquela "guerra" teve conseqüências trágicas e resultados nulos do ponto de vista proletário. Tudo isso o 35 mais ou menos pensa:

nutria sempre uma espécie de despeito por São Paulo ter perdido na revolução de 32. Sensação aliás quase de esporte, questão de Palestra-Corintians, cabeça inchada, porque não vê que ele havia de se matar por causa de uma besta de revolução diz-que democrática, vão "eles"!... Se fosse o Primeiro de Maio, pelo menos... (Idem, p.42)

Como se vê, o próprio personagem estabelece o paralelo entre as suas experiências - a de 1932 e a de 1935. Isso explica o seu processo psicológico diante do Palácio das Indústrias e na Praça da Sé.

5 Os acontecimentos de máxima tensão deste conto são a ida à celebração patronal-governista no Palácio das Indústrias e a ida-meio-fuga ao "motim" da Praça da Sé.

A decisão de ir até o Parque Pedro II foi tomada ainda pela manhã e constitui um prodígio de configuração de processo político-psicológico:

em São Paulo a polícia proibira comícios na rua e passeatas, embora se falasse vagamente em motins de-tarde no Largo da Sé. Mas a polícia permitiria a grande reunião proletária, $\infty$ m discurso do ilustre Secretário do Trabalho, no magnífico pátio interno do Palácio das Indústrias, lugar fechado! A sensação foi claramente péssima. Não era medo, mas por que que a gente havia de ficar encurralado assim! É! é pra eles depois poderem cair em cima da gente, (palavrão!) Não vou! não sou besta! Quer dizer: vou sim! desaforo! (palavrão), socos, uma visão tumultuária, rolando no chão, se machucava mas não fazia mal, saiam todos enfurecidos do Palácio das Indústrias, pegavam fogo no Palácio das Indústrias, não! a indústria é a gente, "operários da nação", pegavam fogo na igreja de São Bento ... mas que pegar fogo em nada! ... é melhor a gente não pegar fogo em nada; vamos no Palácio do Governo, exigimos tudo do Governo, vamos com o General da Região Militar, deve ser gaúcho, gaúcho só dá é farda, pegamos fogo no palácio dele. Pronto. Isso o 35 consentiu, não porque o tingisse o menor separatismo (e o aprendido no Grupo Escolar?) mas nutria uma espécie de despeito por São Paulo ter perdido na revolução de 32. (Idem, p.42)

Num certo sentido, temos encenada a luta de classes na cabeça desse trabalhador. Depois de se dar conta de que o pátio interno do Palácio das Indústrias é uma ratoeira (não é preciso explorar a metáfora), para a qual o proletariado está sendo 
atraído e onde se dará um massacre, não necessariamente a poder de armas de fogo (embora elas estejam disponíveis), como um estrategista, o 35 examina as possibilidades de reação do seu exército. Primeiro, a fúria incendiária em resposta ao elemento surpresa, não por acaso descartada após a lembrança da Igreja de São Bento e, depois, o bom senso prevalecendo, reivindicações apresentadas ao Governo. Mas com o General inimigo não tem conversa: é incêndio mesmo. Eis a equação: com os equipamentos de trabalho e com o poder celeste não se mexe; com o poder civil, dialoga-se; mas contra o poder das armas, fogo. Neste ponto temos a expressão máxima do já mencionado espírito de sacrifício. Ao imaginar um turumbamba com tais desdobramentos, é na revolução proletária que o 35 está pensando. Aliás, está contrapondo a "revolução deles", a de 32, à sua, que poderia começar neste Primeiro de Maio. Não se trata, portanto, de um sacrifício qualquer:

Se fosse o Primeiro de Maio pelo menos... O 35 percebeu que se regava todo por "drento" dum espírito generoso de sacrifício. Estava outra vez enormemente piedoso, morreria sorrindo, morrer... Teve uma nítida, envergonhada sensação de pena. Morrer assim tão lindo, tão moço. A moça do apartamento... (Idem, ibid.)

O sacrifício é ainda maior do que parecia inicialmente, mas parece ser pela melhor das causas.

Depois do "almoço" (não conseguiu comer), ele foi à celebração oficial:

Não eram bem treze horas e já o 35 desembocava no Parque Pedro II outra vez, à vista do Palácio das Indústrias. Estava inquieto mas modorrento, que diabo de sol que acaba com a gente, era por causa do sol. Não podia mais se recusar o estado de infelicidade, a solidão enorme, sentida com vigor. Por sinal que o parque já se mexia bem agitado. Dezenas de operários, se via, eram operários endomingados, vagueavam por ali, indecisos, ar de quem não quer. Então nas proximidades do palácio, os grupos se apinhavam, conversando baixo, com melancolia da conspiração. Polícias por todo lado. (Idem, p.43-4)

O enquadramento está completo: o personagem já tem consciência do seu estado de infelicidade, conseqüência de sua solidão e desorganização. O próprio entorno lhe apresenta o termo de comparação: "os grupos se apinhavam, conversando baixo" e ele não tinha sequer alguém com quem praticar aquela "nostalgia da conspiração". Tão grave quanto o seu estado de infelicidade solitária é a visão dos policiais predominando na cena.

Para completar o desastre existencial, a única pessoa conhecida, quase amiga, a se apresentar, é o guarda de trânsito (grilo) 486, um sujeito desprezível aos olhos do 35: se dizia anarquista mas era um covarde; valentão de garganta, na realidade um medroso. A conversa dos dois só serviu para piorar o ânimo do 35 e nesse estado finalmente ele presencia a violência de classe em pessoa: os prepostos dos donos da vida ("aqueles três homens bem vestidos, se via que não eram operários"), tentando parecer amistosos, mandavam todo mundo entrar. E agora sentindo medo, ainda 
assiste à última cena que sua disposição celebrativa lhe permitia imaginar: "Foram todos obedecendo, se aproximando das escadarias, mas o maior número longe da vista dos três homens, torcia caminho, iam se espalhar pelas outras alamedas do parque, mais longe" (Idem, p.44).

Os que se dirigiram ao parque no mesmo estado de desorganização obedeciam à ordem dos donos da vida. O 35 entrou em pânico, mas continuou ali, resistindo. Deu-se conta de que predominava lá dentro o número dos "bem vestidos", de que a ratoeira era real e entendeu que estava prestes a participar daquela "mascarada de socialismo" só tornada possivel porque ele, assim como os que entraram na ratoeira, se encontravam "naquela desorganização trágica". A gota d'água veio com a ordem dos "cavalarias, falando garantidos" que não era para ninguém ficar no parque, pois a festa era lá dentro. Ele fugiu e tomou o bonde rumo à Praça da Sé.

Áqui o narrador vai às últimas conseqüências: se a mascarada de socialismo do Parque Pedro II o levou ao desamparo e ao desespero, a multidão agora sequer chegou à sua consciência. Mas ela estava lá (seria um ato público?) e o 35 "ficou parado assim, mais de uma hora, mais de duas horas, no largo da Sé, diz-que olhando a multidão" (Idem, p.45).

Assim Mário resolve literariamente o acontecimento da Praça da Sé. Não tem registro. Em seu alheamento, ele volta a se lembrar da moça do apartamento e às cinco horas a multidão começa a se dissolver "desapontada, porque não houvera nem uma briguinha, nem uma correria no largo da Sé, como se esperava". Não precisamos imaginar a fraude. $O$ trabalhador desiste da sua celebração.

A nova equação político-literária estabelece que ele foi capaz de fugir ao canto de sereia patronal-governista, mas não encontrou alternativa a essa mascarada de socialismo que tão bem compreendera. Ele não sabe, mas celebrou o sacrifício. Não aquele heróico, imaginário, que conduziria a sua classe à vitória, mas o da derrota, da humilhação e da redução à insignificância, da "inexistência fraudulenta", a que foi conduzido por aquela "desorganização trágica".

6 À falta de termo melhor, pode-se dizer que o conto narra uma tragédia moderna, de alcance mundial, cujo epílogo ainda não foi escrito. Mas ao contar a versão paulista da pior derrota sofrida pela classe proletária neste século, Mário de Andrade assumiu o papel de narrador de um round numa luta em andamento. Por isso o desenlace do conto mostra o recomeço deste personagem.

Saindo da Praça da Sé após aquele Primeiro de Maio perdido, ele voltou ao território conhecido, conseguiu finalmente se alimentar direito e finalmente conseguiu encarar os companheiros que, numa significativa peripécia, se aproximaram querendo notícias do Primeiro de Maio. Apesar da tentação de mentir, inventar feitos, o 35 limitou-se a gesticular, desvalorizando os horrores por que passara e, num desfecho bem chapliniano, pôs-se a ajudar o 22, dando-lhe uma lição de solidaniedade. 
COSTA, I. C. Mário de Andrade and the First of May, 1935. Trans/Form/Ação (São Paulo), v.18, p.29-42, 1995.

- ABSTRACT: Mário de Andrade wrote his short story, Primeiro de Maio, between 1934 and 1942. Is was posthumously published in his collection of stories Contos Novos. The following reading dates its action and tries to highlight aspects of the history of the working class struggle. Those aspects are not only related to the day but also stem from this short story formal devices.

- KEYWORDS: First of May; celebration; commemoration; fiction; history; class struggle.

\section{Referências bibliográficas}

1 ABRAMO, F. Depoimento a Teoria e Debate, n.1. São Paulo: Partido dos Trabalhadores, 1987.

2 ANDRADE, M. de. O movimento modernista. In: Aspectos da literatura brasileira. 4.ed. São Paulo: Martins/INL, 1976a.

3 . Táxi e crônicas no Diário Nacional. São Paulo: Duas Cidades, Secretaria de Estado da Cultura, 1976b.

4 _. Cartas a Murilo Miranda. Rio de Janeiro: Nova Fronteira, 1981.

5 _. Primeiro de maio. In: ___ Contos novos. 11.ed. Belo Horizonte: Itatiaia, 1983.

6 Carta de 6.10.32. In: ANDRADE, C. D. de. A lição do amigo. 2.ed. São Paulo: Record, 1988.

7 CARONE, E. Movimento operánio no Brasil (1877-1889). 2.ed. São Paulo: Difel, 1984.

8 DEL ROIO, J. L. 1ํo de maio. Cem anos de luta. São Paulo: Global, 1986.

9 KAREPOVS, D. (Coord.) História dos bancários, lutas e conquistas 1923-1993. São Paulo: Sindicato dos Bancários e Financiários de São Paulo, 1994.

10 TROTSKI, L. La revolución española, 1936-1940. Barcelona: Fontanella, 1977. v.2. 